\title{
Books that Matter. The case of Tocqueville's Democracy in America
}

\begin{abstract}
This article addresses a puzzle in the history of academic disciplines: Why is Alexis de Tocqueville's Democracy in America, once considered a sociological classic, nowadays mostly praised as a classic in political philosophy? Existing approaches emphasize either aspects internal to the text or to the figure of the author, or external factors such as historical contexts and disciplinary dynamics. Our explanation questions the assumption that texts are stable and explores the pragmatic interplay between text-artifact-metaphor. The result is a pragmatic genealogy of the successive material incarnations of Democracy since 1945. This allows us to account for the various meanings that have been associated with Democracy (and Tocqueville) at key historical moments in terms of the cultural work of collectives of agents around the text and its material form so as to make it the icon of certain political and disciplinary projects.
\end{abstract}

Keywords: Tocqueville; Democracy in America; history of the social sciences; social theory; political theory; materiality

\section{Authors information:}

Filipe Carreira da Silva, Institute of Social Sciences of the University of Lisbon; Selwyn College, Cambridge

Mónica Brito Vieira, University of York 


\section{Introduction}

Who reads Tocqueville today? It is difficult for us to realize how great a stir he made in sociology just a few decades ago. We must, so to speak, agree with the coroner's verdict: "Dead by suicide or at the hands of person or persons unknown." Tocqueville is dead. But who killed him, and how? In the 1960s a generation of sociologists was introduced to Tocqueville as a classical theorist alongside Weber, Durkheim, or Marx. Yet by the 1990s Democracy in America did not make it to the top100 most influential books in the sociological community and textbooks paid little or no heed to him. One way of explaining this involves comparing sociology with political science, a field in which Tocqueville has never been more alive.

This article proposes to compare the divergent fortunes of Tocqueville's most celebrated work, Democracy in America (1835-1840; herewith Democracy) in sociology and political science as to shed light into the politics of the book as a key strategic site for the self-understanding, self-legitimising and institutional reproduction of academic disciplines and discourses. Our focus is on post-war United States given the impact the American social sciences have exerted across the globe after 1945 until this day. In this period, the book had divergent fortunes among sociologists and political scientists, subsiding from view for several decades among the former while it was rising to prominence among the latter, namely political theorists and political philosophers. Even though external and internal factors to Democracy are important and need to be taken into consideration, our account for these divergent paths is traced back to the book itself: a mobile physical object giving support to Tocqueville's ideas on democracy in America (and democracy as such) through the ages. Never a fixed object, Democracy emerges from our analysis as a crucial but neglected site for the struggles over the meaning of the work and its 
author.

The key idea behind this study is that ideas have a materiality of their own.

Our understanding of Tocqueville's ideas about the equality of conditions, the tyranny of the majority, race relations in Jacksonian America, and so on is incomplete if we ignore that their inscription in the pages of a book entitled "Democracy in America" is a process at once material and symbolic, one involving a great number of human agents, technological devices, ideological beliefs, institutional practices and academic discourses. At the heart of this process is the book. An ever-shifting object, in which groups of human agents invest much of their time and effort to pursue their material and ideal interests, an object that helps create disciplines as it circulates in lecture rooms, libraries and students' hands. An all too common product of mass-markets and industrial technologies that is granted, for that same reason, the status of a classic $-\mathrm{a}$ special kind of book, which embodies exemplary academic practice and helps reproduce academic identities. This powerful object is also exceedingly fragile. It is always at risk of subsiding from view if we forget to care for it. It is this very contrast we wish to bring into light in here. The key to the paradoxical character of Democracy - a material object and a symbolic icon, withering from view among sociologists since the 1970s yet an undisputed classic for political scientists ever since - resides in its specific materiality, one that has been mechanically reproduced millions of times but that remains unique among the classics of social and political thought.

\section{Our Approach}

What explains the concomitant death of Tocqueville, the sociological classic, and the zenith of Tocqueville, the "patron saint" of so much work in empirical political 
science today? Why has Tocqueville's major work, Democracy in America, ceased to capture the attention of sociologists, while among political theorists it is now hailed as an undisputed classic?

We propose to solve this puzzle by approaching Tocqueville and Democracy in a fundamentally different way from existing approaches. Current approaches to the history and sociology of scientific disciplines emphasize either internal aspects such as the author's theoretical genius or methodological lessons, or external factors such as the institutional and sociocultural contexts in which they worked or positioned themselves, or a combination of the two.

The epitome of an internalist approach to Tocqueville is the Straussian quest for the hidden meaning of the work. In their meticulous attention to textual structure and utter unconcern for the relevant social, economic, and political contexts, Tocqueville commentators such as James Ceaser (1997), Delba Winthrop (1986), Peter Lawler (1993), and Harvey C. Mansfield (1995) are all worthy representatives of the radically internalist approach inspired by Leo Strauss' refusal of historicism, i.e. the tendency to reduce the meaning of the text to factors external to it (see also Masugi 1991). Whilst influential in the humanities, its impact upon social scientists is limited.

Externalist interpretations have long dominated the sociological and political scientific reception of Tocqueville in America. Two examples suffice to illustrate this. Political theorist Cheryl Welch contrasts the reception of his work in post-war America and France by reference to intellectual and political factors operating in each country. Welch's cross-national comparison is instructive but has little to say about lines of disciplinary cleavage (but see 2001: 218, 235). Sociologist James Abbott (2007) focuses more explicitly upon the sociology-political science cleavage but, 
again, in broadly externalist terms. Abbott's explanation is that sociology as a whole has gradually moved away from a critical analysis of democracy, which he identifies as the "very essence of the Tocquevillian enterprise," and toward espousing faith in democracy, at the heart of which is a broadly shared commitment to egalitarianism (2007: 62). As a result, Abbott's explanation is flawed, due to both its impressionistic institutional diagnosis and for ignoring the successive transformations of the material form of Democracy and how this has impacted upon its reception.

Historian Matthew Mancini adopts an ad hoc combination of internalist and externalist approaches (2006: 7-8). His proposal is to focus upon "the changing images" of Tocqueville for American intellectuals, by examining "the several layers of reception from the superficial to the profound," i.e.: "from climates of opinion to a few profound thinkers" (2006: 10-11). But the conclusion that Tocqueville and Democracy have exerted a broadly continuous influence upon American intellectual history from the 1830 s to the present day fails to account for significant variations of its impact over time or across disciplines. In short, Mancini's flat reception-history, however informative, has nothing to say about why Democracy (and Tocqueville) have been simultaneously canonized in political science and decanonized in sociology.

There are problems with both internalist and externalist approaches that their mere combination does not resolve. In both cases, texts are assumed to be stable, fixed, and unimportant, and attention is either drawn to the human agents involved in its production or interpretation, or to the external factors shaping their choices. "The texts - the logic and evidence - were, for all practical purposes, constant," argues Hamilton (2003: 281). Likewise, Conal Condren believes, the ideas of those we call the "classics" of social and political thought are "fixed in the mordant of ink. They are 
dead and dyed." From this (misleading) assumption, Condren then goes on to suggest that the intellectual challenge lies in "overcoming their fixity in the face of new problems and possibilities." (1985: 259) But texts are never constant. They are inherently unstable, and only exist in their successive material incarnations. Choosing not to ignore, but rather to explore, this instability is what makes the interpretation of classic texts, such as Tocqueville's Democracy, challenging, thus potentially rewarding. Republished more than 150 times and translated into 15 languages (Nolla 2009: xlvii), the material form of Tocqueville's book has changed dramatically over the years and will continue to do so in the future. Yet even the more historically minded Tocquevillian scholars, such as Mancini, tend to adopt an aesthetic, rather than a sociological, approach to the book. As we will show, however, only a sociological approach to the book can help us unravel the puzzle of Tocqueville's contrasting destinies in sociology and political science. Our sociological approach to Democracy is pragmatic in character, involving a genealogy of the book as a material artifact.

Our conception of genealogy is the exact opposite of tracing a pedigree. Following Nietzsche and the late Foucault, our genealogy of Democracy moves away from celebratory readings and material constructions of the work, which can be found either in the way the book is introduced or even more glaringly in the excision of certain chapters from abridged editions, towards exposing it as a site of power struggles over the meaning of democracy in America (Margree and Bhambra 2011: 119). Methodologically, this involves "following the book" throughout history. This entails a documentary analysis (Scott 1990) of exemplars of key editions in English (both full and abridged versions) published between the 1830s and the present day with a view to document and expose the struggles over its meaning. A crucial outlet 
for these struggles is the paratexts of these editions (Genette 1997). Primary sources include the "working manuscript" and notes handwritten by Tocqueville in the 1830s, correspondence between Tocqueville and various interlocutors concerning the original publication and translation of the book, and correspondence pertaining to the editorial politics behind three key reprints of the work in the 1940s and 1960s.

We mobilize American philosophical pragmatism, namely its insights regarding materiality, as to complement our genealogy of Democracy. We begin with G.H. Mead's little known neo-Hegelian theory of objects, namely, his highly original conception of "social object" (Mead 2011: 21-44) according to which objects arise as objects as they become embodied in the responses of the individual manipulating them. It is this "embodiment of the object" in the responses of the individual that is "the essential factor in the emergence of the physical thing" (2002: 125). For a thing as Democracy in America to arise as a thing, it needs to have a common meaning to the participants in the social act, i.e., it needs to be a "social object." For Mead, to affirm the sociality of Democracy is to stress three different features. First, it means that Democracy elicits social relationships, that is, the production and reception of the book has involved the collaborative effort of a large number of human agents, from the author to editors, printers, typists, translators, commentators, and so on. Second, Democracy motivates reflective thinking as people make use of it in their everyday life. Third, the meaning of Democracy is not merely ambiguous but downright contestable as (often contradictory) claims are continuously made, and arguments exchanged, as to its meaning and implications. Relational, reflective, contestable; such is Mead's pragmatist understanding of the book as a "social object."

As we approach Democracy as a "social object," our assumption is that the meaning of the work is neither a purely textual affair nor is to be reduced to the 
impact of external causes. Rather, the meaning of Democracy emerges out of hermeneutic encounters between text and readers in certain contexts. Crucial for setting the stage for the re-enacting of these encounters are scholarly reviews of new editions of the work published in academic journals (on the study of different reviewing cultures, see Livingstone 2005: 394; Rupke 1999; Secord 2001). To account for this process whereby, under certain conditions, a "social object" comes to represent (and embody) a certain sociological current or political persuasion, we turn to Charles Sanders Peirce's semiotics, namely his concept of the "icon."

Like the other founder of semiotics, Ferdinand de Saussure (1983), Peirce too conceives of the relationship between symbolic signs, such as the letters of the alphabet or numbers, and their referents as arbitrary. Yet, unlike Saussure and his post-structuralists heirs (Derrida 1976: 158; Baudrillard 1981: 63), Peirce emphasizes that symbols are not signs without interpreters (1955: 114). Besides interpreters, the reference to material objects in his triadic model is another way in which Peirce helps us move beyond Saussure and his followers. Two of the three basic modes of relationship between signs and their referents are non-arbitrary, i.e. they involve a reference to the world: "Anything which focuses attention is an index," observes Peirce (1955: 109). While symbols cannot be signs without an interpreter, indices cannot be signs without their objects, that is, the book title and the author's name designate the book insofar as there is an object that can refer to. The iconic mode is non-arbitrary in a different way. Icons, such as portraits or statues, formally resemble their objects. This formal resemblance between the signifier and the signified, however, needs not be tangible. This means that a book is a representation of the ideas of its author, and its author's standing in collective memory cannot be properly understood without a reference to it. Crucially, Peirce stresses that the modes are not 
mutually exclusive, and much meaning-production does in fact involve some combination of the three of them.

Our attention should thus be directed to those historical junctures when Democracy became a symbol, an index, and an icon. As a symbol, Tocqueville's book is a text in McKenzie's (1999) sense of a configuration of signs woven together by readers. As an index, it is also an artifact in Mead's sense of a socially embodied object, i.e. it cannot be neatly separated from the ideas inscribed in it. As an index, the book is the theory. Besides being a text (symbol) and an artifact (index), Democracy suddenly became an icon too, i.e. an emblem for interpreters' political hopes and fears, research interests, and disciplinary projects. It became the material embodiment of exemplary practice; in short, it became a classic.

\section{The Postwar Revival}

Democracy's classic status, however, should not be taken for granted. Indeed, in certain periods, and for certain epistemic communities, Democracy has ceased to be considered a classic altogether. Canonization and decanonization are but the opposite facets of the same social process of defining which works deserve, given their relative quality or worth, to be included in (or excluded from) the canon (Guillory 1994; Connell 1997). This process, we argue, involves successive hermeneutic encounters between text and reader. Behind these encounters one finds attempts by editors, translators, and reviewers to define what the work stands for. These attempts, which are bound to fail if certain conditions are not met, are crucial to explain its concurrent canonization in political science and decanonization in sociology. All the more so because, as we show in this section and the next, Democracy's ever-changing material 
form $^{1}$ afforded the possibility of building not just one single overarching icon, but indeed multiple competing icons around it.

The most influential periodization of these various icons is the work of the prominent conservative sociologist, Robert Nisbet. For Nisbet, there had been "many Tocquevilles" since the war. In the 1940s, Tocqueville had been the "prophet of totalitarianism." By the 1950s, he had transmuted into the "anatomist of affluence" and the prophet of the "decline in intellectual and cultural values under democracy." From the late 1950s through the 1970s, Tocqueville changed again, now into the “analyst of equality." (1976-77: 71, 70) Partly because Nisbet ignores the materiality of the work and pays insufficient attention to the various intellectual contexts, his account is irremediably subjective. Mancini suggests that Nisbet's "Tocquevilles" are nothing more than the familiar grievances of the American conservative movement since the New Deal (Mancini 2008: 267). Yet Mancini's alternative explanation, that there has been only one Tocqueville whose influence has been constantly exerted with minor variations since the 1840 s, is even less convincing. In reality, there have been significant variations in the influence exerted by, and meanings associated with, Tocqueville and Democracy over the years. In this section, we propose to account for variations between the 1830s and the 1950s in the United States by tracing the circulation of the manifestly material object known as Democracy in America. We therefore agree with Nisbet that there have been "many Tocquevilles." Yet, contrary to Nisbet's self-legitimizing lineage of conservative Tocquevilles, our genealogy reveals a constant struggle between competing understandings of the work, some conservative, others unmistakably progressive, some successful in enlarging its readership, others less so.

On the eve of World War I Democracy was on the brink of being out of print, 
its access limited to either the second-hand market or to the remaining stock of reprints published between the 1840s and the 1912 Bigelow edition. Deprived of its material form, it proved pragmatically impossible for the text of Democracy to remain the icon it had been since the mid-nineteenth century. The book remained generally ignored and out of sight well into the 1930s. Nineteen-thirty-five marks the centenary of the publication of Part I of Democracy in America. Several articles were published around this time to celebrate the event. One is by Albert Salomon, who laments: "the present lack of interest in (...) Tocqueville.” (1935: 405) However unfortunate this situation was, it is hardly surprising. Indeed, "at that time, it was impossible to buy a single copy of the book in New York," Salomon later recalled. ${ }^{2}$ Things began to change with the publication of two landmark monographs on both sides of the Atlantic. First, in 1938, Yale historian George W. Pierson published Tocqueville and Beaumont in America, and the following year, J.P. Mayer, an anti-Nazi German émigré, published Tocqueville: Prophet of the Mass Age in England. If Mayer likens Tocqueville to Weber and Marx as a seminal analyst of modern mass society, Pierson uses Tocqueville to criticize the centralizing tendencies of the Progressive Era and the New Deal. Pierson and Mayer's role far exceeds that of commentators, however. Each would mastermind the two main editorial initiatives responsible for Tocqueville's postwar revival. Each of these editorial initiatives championed a specific interpretation of Democracy and of its relative significance for the human and social sciences. They did so by means of crafting an icon in the exact sense explained above: that of the material embodiment of exemplary practice, i.e. a classic. But which kind of classic we were to have in our hands was not something simply to be discovered. Rather, it was something to be actively undertaken by means of rhetorical persuasion and typographical construction. 
In late 1944 Lewis Mumford deplored how "relatively inaccessible and too often neglected" (1944: 445) the work is. In the following spring, Mumford's lament was no longer warranted. The Knopf edition, a product of Pierson's efforts, appeared on the bookstands on April 16, 1945. ${ }^{3}$ This is the first, and most successful, edition of Democracy in the twentieth century. The origins of the edition go back to 1938 , when Pierson counselled Alfred A. Knopf to republish Democracy in America, suggesting Phillips Bradley, a Queens College professor of political science, to edit it. Pierson persuaded Bradley not to produce a new translation but rather to revise the BowenReeve text given: "the very great risk that a new translation, however full of the contemporary vocabulary, might be genuinely inferior to the old." ${ }^{4}$ For six years, Pierson closely monitored Bradley's work of making over 1,000 corrections to the Bowen-Reeve text, writing a 30,000-word introduction, and compiling four appendices (Bradley 1945: ci). Tocqueville's original division of the work into two parts was respected. Despite not figuring as co-editor of the Bradley edition (or in any other capacity, for that matter), Pierson was unequivocally the intellectual source behind this path-breaking editorial initiative.

Mancini's aesthetic perspective (2011: 24) leads him to describe the 1945 Bradley edition as "flawed” (2006: 171). This could hardly have been more misleading. Far from flawed, the Bradley edition was a resounding success, decisively framing the work for decades to come. Mayer, who did not hesitate to consider the primary sources of Pierson's seminal Tocqueville and Beaumont in America as "partly faulty and incomplete," (1959b: 352) describes it as "very important" and commends it for having broken: "new ground in many directions." (1959b: 350) Besides offering a more modern rendering of the Bowen-Reeve text, its innovative material form proved very successful in making the text accessible to a new generation of readers. 
The Bradley edition readers have held in their hands a handsomely produced twovolume hardbound book designed by perhaps the most influential and innovative designer of the time - W.A. Dwiggins. In the first five years alone, the hardbound Bradley edition sold 11,000 copies - more than all the previous re-editions combined..$^{5}$ In late 1945, a Random House-Vintage Books paperback version appeared, which was even more successful. Democracy is one of the first works in the social sciences to benefit from the "paperback revolution" (Escarpit 1966), a technological innovation that can be traced to the first Penguin editions of literary classics in the 1930s (McCleery 2002). Pocket-sized, cheap, and with a decisively modern appearance, Tocqueville's book sold in the hundreds of thousands in successive reprints well into the 1960s.

The Bradley edition is decisive for its canonization among sociologists. This involved a collective effort to work through its "ambiguity” (Condren 1985: 284). Such an effort can be characterized in a number of ways: a) to acknowledge the authoritative nature of the source of the book; b) to set it apart from other writings by Tocqueville, often deemed mundane or profane; c) ensuring the book was complete and did not need to be complemented by anything else (although it elicits commentary to expound its meaning), and certifying that the book embodies the ambivalent power to inspire readers to action or dissuade them from pursuing certain courses of action (Olson 2010: 11). An artifact with a modern appearance, Bradley's revised translation of the text is crucially framed by peritexts which portray it as an iconic sociological reflection upon the nature and challenges of democratic egalitarian societies. The Foreword Harold J. Laski wrote for the 1945 Bradley edition is as short as it is controversial. In two-and-a-half pages, the then Chairman of the British Labour Party Executive Council hails Democracy as one of the "seminal sociological works of the 
nineteenth century," remarkable for its "prophetic quality:" "Few writers have seen so magisterially as Tocqueville the difficulties of capitalist democracy." (1945: i) For reasons not difficult to discern, Knopf excluded Laski's Foreword from reprints after 1948, limiting its role as framing the work as a socialist plea for material equality.

The same cannot be said of Bradley's 100-page long Introduction, which would accompany this edition (and the Vintage paperback) throughout its life. While a student of politics, Bradley is chiefly concerned with Tocqueville's "sociological insights." Among these is Tocqueville's seminal contribution to the study of race relations: "What he had to say a hundred years ago about the psychological and the material factors implicit in these relations is as pertinent [today] as when he wrote." (1945: xcix) Tocqueville's work was thus introduced to the postwar generation of American readers as a classic: "sociological inquiry into the implications of democracy." (1945: xciv) Revealing his progressive leanings, Bradley suggests that at the heart of Tocqueville's inquiry are "the problems posed by and resulting from social inequality and its effects on the practice of political democracy. Like Jefferson, he saw clearly enough that social (and economic) inequality leads to the attrition of democratic politics." (1945: xcvi)

Then as now, Bradley's liberal and progressive leanings did not go unnoticed. Contemporary reviews in academic journals acknowledged Pierson's tutelary influence (Sydnor 1945: 458), emphasized its timely appearance ("Some years ago, on hearing that this work was the chief treatise on popular government after Machiavelli and Rousseau, this reviewer spent two years waiting for a copy on order with his book dealers before obtaining his set, printed in 1889," wrote Lancaster Greene, 1945: 556), praised its “major significance, both as a historical document and as a sociological (...) analysis," (Cook 1945: 131), one reviewer portraying 
Tocqueville as a progressive thinker who, if anything, should have gone even further in his appraisal of "popular government generally," (Anderson 1945: 183), another suggesting that he believed: "in the irresistible ultimate advent of a classless society" (Frank 1945: 461; see also Binkley 1945; Kiniery 1945; Wright 1946). The scholarly reception of the Bradley edition, reinforcing its innovative material form and progressively inclined paratexts, was pivotal in setting the stage for hermeneutic encounters between text and readers in postwar America out of which the "social object" known as Democracy gradually acquired a new common meaning - that of a sociological classic.

Isaac Kramnick, author of a biography of Laski, has recently reinforced this idea. His argument is that the early postwar revival is a left-wing affair whose main agents are progressive thinking editors, namely Bradley, Laski, and "Max Lerner, the leftist journalist," who: "was a friend of Laski's as well, and editor with J.P. Mayer of the 1966 edition. The introduction was Lerner's (...)" (2003: xliv). While Kramnick is right to point out the leftist, progressive character of this particular strand of editorial initiative around Democracy, his account leaves out another strand of editorial initiatives that played a crucial role in the struggle over the meaning of Tocqueville in the 1940s and 1950s. This other strand, however, is not ideologically progressive but distinctly conservative (e.g. Kirk 1953: 204-224). The ideological character of these strands is manifest in the physical features of the editions composing them, from the titles of the book series in which Democracy is included to the choice of images to illustrate its cover and, more important, to the rhetorical framing imprinted by the prefaces and introductions upon the work. This conservative strand of editions, then, is but a collective attempt to craft a distinctively conservative icon out of Democracy so that the book and its author will come to materially embody - or will come to 
represent - a number of key (conservative) ideological themes.

\section{Fighting over Democracy in America in the "age of anxiety"}

The first of these conservative initiatives appeared in 1946 in the Oxford World Classics series and was edited by Henry Steele Commager, ${ }^{6}$ one of America's most distinguished "consensus historians." (e.g. Commager 1950) Consensus history revolves around the fundamental claim that the "Jacksonian persuasion" (Meyers 1957) was one of remarkable social harmony and normative cohesion. This was an attempt to respond to the chief social issues of the 1950s - the so-called "age of anxiety" - namely a concern with a nuclear confrontation with the Soviet Union, and domestic issues such as juvenile delinquency, increasing secularization, and alienation. Consensus historians' depiction of Jacksonian America as a golden epoch of harmony, of course, fits uneasily with Tocqueville's copious remarks about racial and social conflict. This means that to present Tocqueville as a conservative icon involved portraying his work as emphasizing well-ordered consensus and downplaying contradictions in American democracy. Although this task involved words, texts, and meanings, it is an error to believe it was a purely discursive task. Rather, it entailed a set of very concrete interventions in the text of Tocqueville's book, in its material form, and in its metaphorical standing on the part of a number of ideologically motivated agents, including editors and reviewers.

The most influential of these agents is perhaps Commager. His edition of Democracy retains the Bowen-Reeve's rendition of the text. Partly constrained by the commercial pressures exerted by the editor at Oxford University Press to pitch it as a cheaper version than the Bradley edition, ${ }^{7}$ however, Commager's edition is an 
abridged version containing about half of the original. This minuscule abridgement (it is printed in 8mo size paper, hardbound, with narrow margins, and exceedingly small print) effectively sanitizes Tocqueville. Commager was the first in a long line of editors of Democracy to offer a celebratory vindication of Jacksonian America, with no mention of its racial tensions and social contradictions. The artifact Democracy is thus systematically purged from all its dissonant elements, including the "three races" chapter. Commager uses the Introduction to frame the modified text-artifact of Tocqueville's book as an unmistakable conservative icon. Portrayed as a precursor of methodological individualism, Tocqueville is said to be one of "the first students of politics to discern the truth (...) that the great forces of history do not operate uniformly and automatically in every society," (1946: xiii), and one of the first to have: "grasped the fact (...) that democracy makes for conservatism and that the surest guarantee of stability is the wide distribution of property." (1946: xxi) The central theme of the work is the danger deriving from the tyranny of the majority. Commager's sanitized version of text-artifact-icon soon proved to be a bestseller. It sold over 20,000 copies between 1946 and $1960^{8}$ (this was such a success for the series that OUP would never bring it out as a paperback), ${ }^{9}$ paving the way for a whole line of editorial initiatives in which Tocqueville is presented as the surest antidote to dangerous Marxist political solutions and epistemology.

A number of other conservative abridged versions soon followed (Heffner 1956, Hacker 1964; see also Kuehnelt-Leddihn 1966). This ideological slant upon the work, however, did not pass unnoticed by reviewers. For instance, James L. Colwell, in an exhaustive survey article (1967), provides a broadly negative review of these editorial projects that he deems more an exercise on political propaganda than strictly academic works (see also Salomon 1959; Resh 1963). 
Despite this critical reception, Commager's and Heffner's abridgements of Democracy are very successful at pitting Tocqueville against Marx. While these conservative editions are fundamentally opposed to the (superior in a scholarly sense) Bradley edition - in their approach to the text, its material form, and what it represents - the fact is that, together, they work towards the first "Tocqueville revival." (Mayer 1959a)

Virtually every reader in the 1950s and 1960s read Tocqueville in one of these renditions, and many must have read the prefaces and introductions to them. Our argument is that these two editorial strands acted as outlets for broader intellectual movements to appropriate Democracy for opposing ends. Caught in the shadow of Marx, Tocqueville is recuperated either to expose the contradictions and tensions of Jacksonian America (and, by extension, of contemporary postwar America), or to praise its exceptional normative consensus and democratic credentials. The reviews of these editions are part and parcel of this recuperation of Tocqueville as an icon for certain political and academic projects. Taken as a whole, reviews seem to be more or less positive due not only to scholarly considerations (e.g. the fact that Commager's introduction was marred with factual errors), but because reviewers, far from being neutral judges, are often deeply involved in the struggle over the meaning of the work and position themselves vis-à-vis the perceived ideological tenor of the edition at stake. This suggests that reviewers, no less than editors, were important agents in the creation of a powerful social object able to project two distinct and contradictory meanings in the decades following the end of World War II. As the Cold War lengthened, the pages and covers of Democracy became the focal point of two parallel attempts to re-assemble text and artifact in order to turn Tocqueville into an icon of conflicting political ideals and academic projects. 
The Bradley edition eventually wins over the conservative abridgements of the 1950s and "Tocqueville, the sociological classic" emerged in the course of the next decade. Ironically enough, the Bradley edition then fell victim to its own success. After having provided the entry-point to Tocqueville for a new generation of progressive-oriented social scientists - Seymour Drescher, who was to become a renowned Tocqueville expert, recalls the emotion with which he read Bradley's edition of Democracy for the first time in 1954, even having written a poem about it (Mancini 2006: 226; see also 177) - scholarly and commercial pressures increased to have its material form adapted to its newly acquired classic status. In 1966, Harper \& Row published the first English translation of Democracy since Reeve's. ${ }^{10}$ The era of Bradley as the text of choice was over.

\section{One book, two disciplines, many Tocquevilles}

As George W. Pierson, one of the all-time experts on Tocqueville, had masterminded Bradley's edition, one finds another distinguished Tocquevillian behind the 1966 Harper \& Row edition, none other than the editor of the definitive edition of Tocqueville's complete works, J.-P. Mayer. With funding provided by Harper \& Row in 1960, Mayer brought his friend George Lawrence on board to translate the work.

This edition ripped the benefits of the mass-market Democracies of the 1940s and 1950s, which reached a significant portion of the reading public of the time. But it also moved the scholarly benchmark higher. Impeccably produced, and offering a new translation of the work, the 785-page-long volume was received avidly. Laudatory reviews appeared in major academic journals. Durand Echeverria, an expert in French history and culture, expressed his gratitude to the editors for having 
produced: "for the first time in 126 years an English version of what Marx Lerner justly calls the 'greatest book ever written on America' that in both form and content reproduces the original.” (1967: 638) In her review for the Journal of American History (1967), Lynn L. Marshall applauded the sound scholarly fashion in which the book was edited (1967: 378). Excitement about the new edition would spill over to Book Week. Its 1966 Christmas issue did not hesitate in reserving space in two of its pages to the new editorial sensation (Ward 1966).

The new translation contributed decisively to the general interest. As Mayer stresses in the Foreword, over 100 years old, Reeve's translation was an inevitably “dated text,” which neither Bowen's nor Bradley's revisions could salvage. Deemed "faulty" and "inadequate for the needs of the contemporary reader," (1966: vii) it was in need of replacement. Bradley himself, Mayer observed, recognized this much in his Introduction to the Vintage edition. But, more importantly, the new translation served “the author's wish:" (1966: viii) Tocqueville had expressed serious doubts about Reeve letting his distaste for democracy imprint itself on his text, thereby corrupting the book's character: "which is a veritable impartiality in the theoretical judgment of the two societies, the old and the new, and even the sincere wish to see the new one establish itself." (Tocqueville 1951: 47) With funding provided by Harper and Row in 1960, Mayer could bring his friend George Lawrence on board to translate the work anew, respecting the author's intention. Lawrence had already been the translator of Mayer's edition of Tocqueville's Journey to America. In his search for fidelity to the original, Mayer closely supervised Lawrence's translation, reading his text, comparing it with the original, and revising Lawrence's renditions whenever necessary, as well as consulting nearly all the books and documents to which Tocqueville refers in the process. 
The 1950s and 1960s witnessed a steep rise of interest in Tocqueville. The 1966 Mayer-Lerner edition of Democracy in America crowned it. The new translation, framed by paratexts presenting Tocqueville as a political sociologist and the forerunner of many specialized subfields within the discipline, reads as a canonization of Tocqueville as a sociological classic. By the time it was published, Tocqueville's name had become common currency in a wide variety of disciplinary subfields, from national character studies, abounding in American history and American studies departments, to the American pluralist literature which poured from political science departments. In the postwar period, pluralist social and political thought turned to ideas of civil society. The study of voluntary associations, pressure groups, and political culture occupied political scientists. Tocqueville's views on democracy's dependence upon a robust associational life and a thriving civic culture capable of counteracting the perils of excessive centralization and federal bureaucracy was a cornerstone of much American pluralist thought of the time. This was also the Tocqueville most commonly highlighted in American social science during the Cold War, as it erected its own stark wall between, on the one hand, American liberal democracy and, on the other, totalitarianism. As we see in Mayer, "totalitarianism" was the term he used to conceptually link dictatorships on the right and left in the mid1930s, but which came to be employed mainly as a synonym for communism during the 1950s and 1960s, when the assertion of a resolute divide sought to banish ideas that we see voiced by Mayer, i.e., a contiguity between mass democracies and totalitarian states and capitalist societies (through their culture industries) harboring totalitarian tendencies.

Evidence abounds in the 1950s and 1960s that Tocqueville came to be seen as the author that best captured the character of the American and American social life. 
Drescher quantified this burst of interest in Tocqueville and Beaumont on Social Reform (1968) by showing that almost half (44\%) of all existing Tocqueville scholarship appeared between 1950 and 1968 (1968: 200). This was certainly true in sociology. Admittedly, Tocqueville never made it to the inner core of the sociological canon. Still, besides Salomon, Nisbet, and Riesman, a number of prominent figures in the discipline claimed Tocqueville as their intellectual mentor. Examples include Seymour Martin Lipset, the political sociologist who saw his examination of the basis of democracy in Union Democracy (1956) as being close to Tocqueville's. Reinhard Bendix, a dominant (indeed founding) figure in the Berkeley department of sociology, undertook an analysis of political modernization, or of how state and civil societies interact in the formation of new political communities, in Nation-Building and Citizenship (1964) which is inspired by Tocqueville (and Weber). Edward Digby Baltzell sought the model for his own analysis of the rise and fall of the Protestant establishment in America (1964; see also 1962) in Tocqueville's The Old Regime. Tocqueville's influence is further attested by his incorporation in readers and textbooks of the time, albeit with significant differences depending on the specific genre from which the text emerged. Don Martindale, in The Nature and Types of Sociological Theory, a treatise written in the pluralist genre inaugurated by Sorokin in the 1920s, describes Tocqueville's Democracy in America as one of the studies responsible for turning political science into an empirical discipline in the context of the birth of the social sciences in the $19^{\text {th }}$ century (1960: 39). In the famous "The Calling of Sociology" epilogue to Theories of Society (Parsons, Shils et al. 1961), where he discusses the nature and functions of the sociological canon, Edward Shils positions Democracy in America not as one of those great works that are the antecedents of modern sociology such as Aristotle's Politics or Adam Smith's Theory 
of Moral Sentiments, neither as a modern sociological classic as the writings of Weber or Durkheim, but rather as one of those "works of analytical scholarship and reflective observation," which "retain a freshness and pertinence to contemporary sociological analysis - despite the corrections and improvements that later scholars can bring to them - for the same reasons that the great classics of social and political philosophy retain their power." (1961: 1447)

Yet the most enthusiastic and systematic endorsement of Tocqueville's sociological contributions came in the form of treatises written in the humanist genre, in which texts are evaluated based on their immortal lessons and literary qualities, with an explicitly conservative tone. Raymond Aron's Les Étapes de la Pensée Sociologique, the book which did the most to elevate Tocqueville to the status of founding father of sociology, was first published in France by Gallimard in 1965 and 1967 (first and second volumes, respectively), and was quickly translated into English by Anchor Books, the oldest trade paperback publisher in America, as Main Currents in Sociological Thought, in 1968 and 1969. In The Sociological Tradition (1966), Nisbet concurred. For Nisbet, problems of order, loss of meaning, and loss of community afflicting the modern world all point to the importance of values, shared assumptions, and associational life in guaranteeing some form of social stability and progress. They also suggest the need to read the classic texts of the sociological tradition. For Nisbet, Tocqueville ranked alongside "Marx, Weber, and Durkheim" as one of those men who laid "the foundations of modern sociological thought." (1966: 5) For its part, Democracy in America is presented as a timeless and fundamental contribution to the discussion of the unit-idea of "authority," (1966: $107 \mathrm{ff}$.) the "first systematic and empirical study of the effects of political power on modern society," (1966: 120) and prefigures Tocqueville's analysis of centralization and 
bureaucratization in The Old Regime. As text and as artifact, the new and impeccable rendition of Democracy embodied a definite understanding of humanist-inspired, pluralist political sociology. These differences in treatment by influential 1960s commentators foreshadow what was to happen to "Tocqueville, the sociological classic" in the next decade.

An examination of introductory sociology textbooks, which are the primary teaching device whereby students learn about sociology and are presented as representative of the field of study, confirms Tocqueville's sociological canonization in the 1950s and 1960s. But it also introduces a crucial development: Tocqueville's gradual demise after the 1970s. Our analysis of 59 sociology textbooks published in the United States between 1958 and 1980 reveals a remarkably stable presence of reference to Democracy, including in the undisputed market leader, Broom and Selznick's Essentials of Sociology (1958), up to the mid-1970s. ${ }^{11}$ Our findings show Tocqueville's Democracy in America being cited at least two times in the following textbooks. Between 1958 and 1962, four out of ten textbooks cite Democracy at least twice, including Broom and Selznick (1958), the dominant introductory sociology textbook in the 1960s and 1970s (the other three were Chinoy 1961; Green 1960; Williams 1960). Likewise, in the 1963-1967 period, Bensman and Rosenberg (1963), Gouldner and Gouldner (1963), Smelser (1967), and Wilson (1966) refer to Democracy at least twice. In the 1968-1972 period, Allyn (1972), Lowry and Rankin (1969), McKee (1969) and Popenoe (1971; the 1974 edition contains an augmented treatment of Tocqueville) cite Tocqueville's text multiple times. From the mid-1970s onwards, however, the relative decline of interest in the work begins. Between 1973 and 1978, three out of ten sociology textbooks introduce students to Democracy including the market leader from the late 1970s onward, Ian Robertson's Sociology 
(1977) (the others were Whitten and Bennett (The Study of Society, 1973), and Shepard 1974). In the 1978-1980 period, only four out of nineteen cite Democracy more than once: Almquist et al. (1978), Light and Keller (1979), Ritzer et al. (1979), Spencer (1979).

Our analysis also points to a qualitative change in the way the work is presented, which may help account for its demise among professional sociologists in the coming decades. Whereas in the textbooks of the earliest period Tocqueville is cited with virtually no discussion of his general sociological theoretical orientation, in the textbooks of the 1963-67 period his work begins to appear as an exemplar of "humanist sociology" that is contrasted, on the one hand, with "scientific" and, on the other, with "action-oriented" sociology. A similar pattern is discernable in the textbooks from the 1968-1972 period, which frame their treatment of Tocqueville's Democracy within broader analyses of sociology as an art (as opposed to as a science). The effects of the Mayer edition of 1966 are apparent. This, however, does not seem to be a lasting effect. From the mid-1970s onward references to Democracy in sociology textbooks occur within the three competing perspectives - functionalist, conflict, and symbolic-interactionism (Herrick 1980: 618) - that will structure the majority of textbooks right up to the present day. Sociology textbooks of the 1973-78 and $1978-80$ periods tend to fit the book within the rigid "paradigm model", either as a forerunner of the study of a core component of functionalism - "institutions," defined as "stable clusters of values, norms, statuses, roles and expectations around basic needs of a society" (Robertson 1977: 81; 412) - or as an exemplar of the "pluralist" approach to politics alongside Durkheim in contrast to elitist theory and Marxism (Spencer 1979: 410). Such a skewed, reductionist paradigm model is less of a congenial framework from which to approach the book than a more inclusive, 
heterogeneous, problem-oriented model would be. This suggests that changes in the way sociology students were introduced to the discipline from the 1970s onward contributed to Democracy's eventual demise among professional sociologists.

These findings, which have the ever-changing material form of the work at its epicenter, shed new light into well-known disciplinary developments. As Michael Burawoy explains, sociology in the 1970s "moved to accommodate critical perspectives, absorbing the blows directed its way by becoming more open to political pressures. Subfield after subfield thus moved to the Left." (2005: 70) As the discipline moved away from the liberal consensus of the postwar period toward an epistemological eclecticism, which celebrated methodological difference and theoretical diversity while addressing social and political concerns regarding race and gender relations, intellectual interventions by editors-cum-commentators in and on Democracy ceased to resonate with sociological audiences as they once did. As a result, Democracy gradually withered from view in sociology (Abbott 2007). The era of the likes of Mayer, Aron, and Nisbet, for whom sociology could still be considered an "art form" with Democracy affording readers a "landscape," as "distinctive and compelling as any to be found among the greater novels or paintings" ([1976] 2002: 7) of its age was coming to an end.

\section{Tocqueville today}

The contrast with contemporary sociology could not be more striking. Democracy in America is "simply not regarded today as crucial to the training of professional sociologists (...) as opposed to well-read undergraduates or scholars of other kindred disciplines," laments John Torpey (2006: 696; see also Kasinitz 2006), editor, with 
Stephen Mennell, of one of the last selections of Tocqueville's writings specifically aimed at a sociological audience (Tocqueville 1980). In many ways this results from a long-term trend, with theorists that sought to define the sociological canon - Parsons, Merton, Mills, Bourdieu, Collins, Alexander, Habermas - giving, at best, cursory treatment to Tocqueville.

The 1970s and early 1980s marked the ascendency of the communitarian Tocqueville, or Tocqueville as a critic of individualism and the resulting atomization and privatization of societies. Robert Bellah's Habits of the Heart (1985) drew its title and some of its inspiration from Tocqueville. It diagnosed the malaise of modern American society and in a Tocquevillian vein urged it to draw on its diverse civic and religious traditions to rebuild itself as a democratic community capable of resisting the dehumanizing effects of the market and the administrative state. The book became embroiled in vigorous popular and scholarly debate, namely the liberal/communitarian debate that was then peaking amongst political theorists, and was often cited in that context. But despite the controversy surrounding it, Bellah's book did not trigger a Tocqueville revival in sociology. Likewise, later attempts to reestablish Tocqueville's status as a classic seemed to fall on deaf ears in the sociological community (Pope 1986). Even the burgeoning literature on "social capital" in the 1990s and 2000s, following the revival of Tocqueville instigated by Robert D. Putnam's work (1993) on the effects of associations on the development of the civic capacities that sustain democracy - and their purported corrosion since the 1960s (2001) - was mainly a political science affair, with some spilling in political sociology. It was also an affair greeted with early skepticism by sociologists on the democratic left, who saw a danger in Putnam's "Tocqueville romanticism," or the idea that "social capital" arises somewhat ex nihilo, in a realm apart from politics and 
government (Skocpol 1996).

More recent attempts to rehabilitate Tocqueville for sociologists, notably by Jon Elster (2009), Raymond Boudon (2006), and Richard Swedberg (2009), have failed to gain center stage in the discipline. Textbooks, again, provide a valuable indication of Tocqueville's near-complete neglect among sociologists. ${ }^{12}$ The same is true in social theory textbooks. While Baert and Silva (2010: 118) present Tocqueville as a classic in social theory, and discuss contemporary appropriations of his thought, Seidman's Contested Knowledge makes only one reference to Tocqueville. Lemert's (2013) sweeping multicultural overview of social theory readings begins in 1848 with Marx. If contemporary sociology textbooks pay little or no heed to Tocqueville, the same seems to be the case with the sociological community. In 1998 members of the International Sociological Association (ISA) found no place for Democracy in America among the books which were most influential on their work as sociologists. ${ }^{13}$ They were more likely to trace their research agendas back to the work of Du Bois, Harriet Martineau, or Jane Adams than to Tocqueville. "Dead by suicide or at the hands of person or persons unknown:" the fate of Tocqueville in sociology seems to agree with the coroner's verdict.

In neighboring political science, however, the reception of Democracy has been strikingly different. Far from dead, Tocqueville and his magnum opus could not be more alive among political scientists, namely political theorists and political philosophers. A direct comparison between the two disciplines in terms of the references to the work in textbooks is not recommended, however, since political theory courses have been significantly less taught using only textbooks since the 1970s (Moore 2017: 531). As an alternative illustration of the divergent fortunes of the work in sociology and political science in America, we have compared the 
references to Democracy in the main journals of each discipline between 1960 and 2010. The figure below summarizes our findings.

Figure 1

Number of references to "Democracy in America" in Sociology and Political science journals, 1960 2010

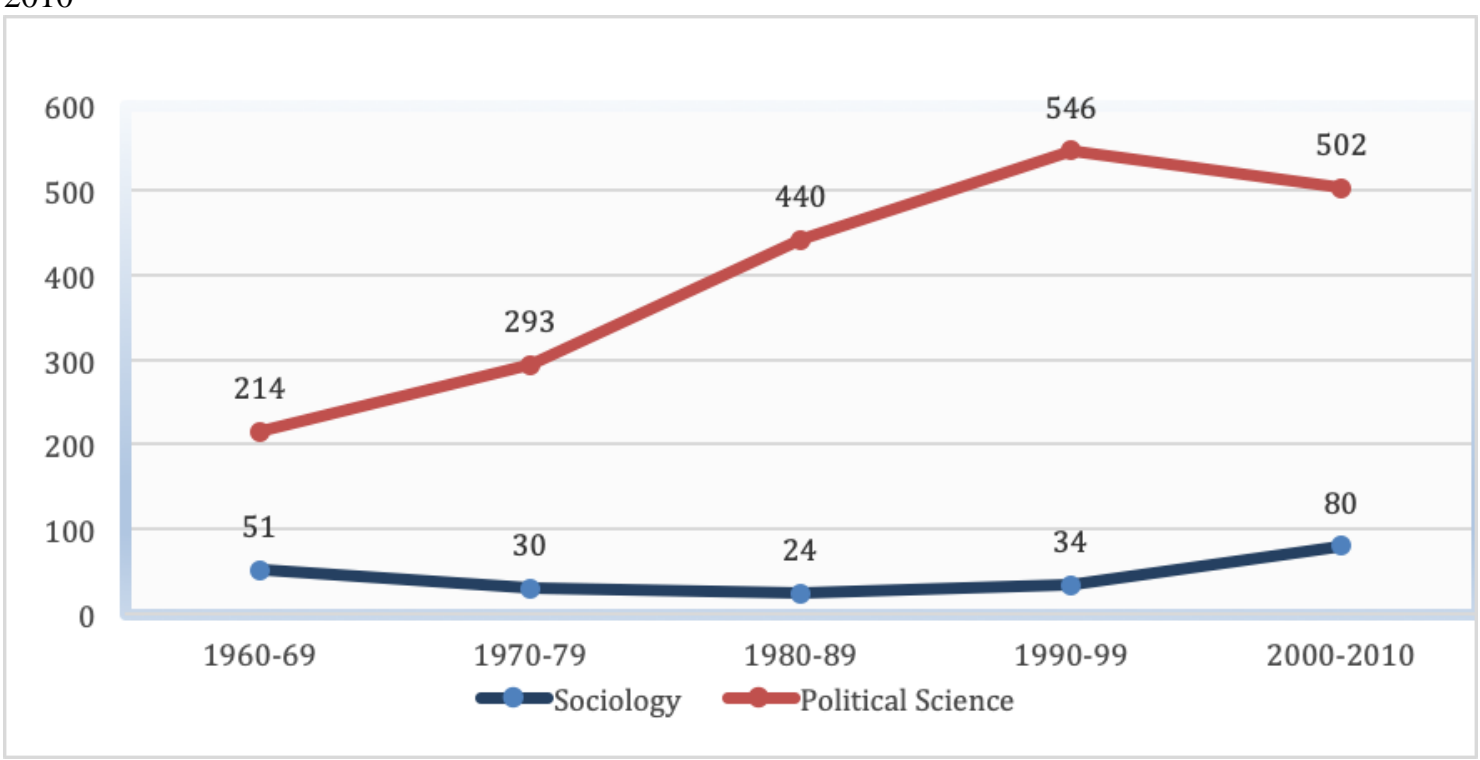

The significant increase in the number of references to Democracy in political science journals since the 1960s is a measure of the canonization of the work, i.e. of the extent to which the book came to function as a material signifier of exemplary practice - in short, a classic - among practitioners. The very difference in the total number of references in the two disciplines, almost ten times more in political science $(\mathrm{N}=1995)$ than in sociology $(\mathrm{N}=223)$, cannot be explained by the differences in dimension of those two epistemic communities alone. In the case of sociology, the relatively low number of citations in the 1960s, when Tocqueville's canonization among sociologists reached its peak, is explained by not only the fact that Tocqueville never occupied a central position in the sociological canon but also because two of the seven journals considered here were yet to be created (in addition, of the remaining five, The 
American Sociologist only begins in 1965). In turn, as hinted above and confirmed by our qualitative analysis of the references in question, the increase in references after the 1990s in sociology journals is by and large due to a spill-over effect from political science, namely articles on voluntary associations and civic trust, and, to a much lesser extent, to historical articles revisiting Democracy as a means to discuss the politics of canon-formation in the discipline. This has striking parallels to what happened with Du Bois' The Souls of Black Folk, one of the latest works to join the sociological canon in the wake of a wave of re-editions of the work in the 1990s. Very much like Democracy, Souls was canonized in sociology through the work of agents who were not sociologists: in the latter case, by academics specializing in literary criticism, American literature and cultural studies (Silva and Vieira 2019). In any case, our findings provide strong evidence of not only the relative decline of Democracy in the sociological imaginary between the 1960s and 1990s, but also of its peripheral position in absolute terms in this period.

They also raise two interrelated questions, though. First, what happened in terms of the politics of the book that accounts for the peak in Democracy's canonization among political scientists and the partial recovery in interest by sociologists since the 1990s? Second, what does our approach enable us to say about the politics of canon-formation in general? We take the first question in the remainder of this section and leave the second for the conclusion.

The 1980s mark a momentous shift in the politics of Democracy. Until then, reading Tocqueville through Democracy had the effect of turning him into either a social scientist or a historically sensitive political thinker whose brilliance put him a par with other classics such as Weber or Marx. In the 1980s, however, a new cultural icon emerges: that of Tocqueville, the "aristocrat liberal" who "fears big government" 
most of all (Kramnick 2003: xliv). This betrays the appropriation conservative intellectuals have made of Democracy, an appropriation that can be traced back to the celebration of the $150^{\text {th }}$ anniversary of the publication of the two volumes of the work, in 1985 and 1990 respectively (Kramnick 2003: xliv; Kammen 1998: 38). But this new icon - "Tocqueville, the neoconservative superhero" - is not simply the result of quasi-mechanical impact of external factors such as the influence of neoliberalism. Neither is it the product of free-floating signifiers, as in a purely discursive struggle over the meaning of the work. The origins and character of this new icon, we contend, can only be properly understood if one considers the cultural work of certain key collectives of agents around Democracy as text and artifact. Indeed, the attempt of cultural appropriation by conservatives did no pass without opposition. In the intervening years Democracy became, once again, the battleground in the struggle over the meaning of the work. This time, the struggle does not stop at the paratexts (although it included them). The focus is now in how to have Democracy more adequately translated into English.

The translation war that follows is perhaps the most significant aspect of the politics of Democracy in this period. At stake are two opposing understandings of what counts as "the study of the book" and how the relationship between the book's content and its material embodiment is ultimately conceived (Goldhammer 2003: 116). On the one hand, there are those for whom texts are self-sufficient objects of inquiry. They follow Leo Strauss' model of the ideal translator, which combines literalism (or fidelity to individual words and sentence structures rather than meaning) with elitism. This is the understanding behind the 2000 Chicago edition of Democracy, translated and introduced by Harvey C. Mansfield and Debra Winthrop, the first English translation of the work since Lawrence's back in 1966. On the other 
hand, there are those who see the text as part and parcel of a larger socio-cultural system, the analysis of which is indispensable for the correct understanding of the meaning of the text. This approach can be seen behind editorial projects such as Gerald Bevan's translation for the Penguin Classics edition of 2003, Stephen D. Grant's translation for Hackett Classics (2000), or James T. Schleifer's translation for the Liberty Fund in 2000, in an authoritative four-volume bilingual set, which used as template Eduardo Nolla's French critical edition for Vrin (1990). The best exemplar of this approach, however, is Arthur Goldhammer's translation for the Library of America edition of 2004.

Mansfield and Winthrop, as self-professed "students of texts", seek to do justice to Tocqueville as the "deep thinker" (2000: 154) he truly is, even at the expense of readability. As Straussians, their aim is not to resolve contradictions in the text (what Tocqueville must have meant or ought to have meant), but to interpret them as part of the truth. The truth is that these contradictions and ambiguities encode deeper meanings, which must be left untouched by the translator. They constitute real passageways to the intentions of the author, whose arduous excavation is the task of the philosopher. Hence the need of leaving "the difficulty to be seen by the reader," for otherwise "one deprives him of a discovery that might force him to think", they write (Mansfield and Winthrop 2000: 156). In short, they see the text as a "cypher" encoding the message left by the author. Goldhammer sees things rather differently. For him, Democracy is a cultural artifact, the translation of which involves a shift between cultures as to give the text a similar function in the target cultural system. This entails the translator to develop a "good ear", or practical knowledge, of the history, culture and convention of both the original and target language (Goldhammer 2003: 118). Translation, from this perspective, is less a matter of deciphering hidden 
messages (and language less an algorithm for performing encryption) than something akin to a musical performance, in which the interpreter must preserve a sense of the original's qualities as they play on both the original and the sensibilities of the target cultures. Reviews of the Mansfield-Winthrop translation that subscribed to this perspective were, unsurprisingly, highly critical of it either because of its ideological tenor (interpreting Tocqueville as arch-conservative), or because of the pitfalls of their quest for literalness. They showed how the word-for-word translation often resulted in distortions in which meaning was either confused or lost (e.g. Drescher 2001). Other critics reacted more sharply to the philosophical elitism underpinning Mansfield and Winthrop's translator choices. This is perhaps the aspect where their translation departed more dramatically from that of Lawrence in 1966. While the Harper and Row 1966 edition presented Lawrence's translation as an effort to combine "brilliance" with the duty of making the text "readable" to the contemporary mass public, the Mansfield-Winthrop translation replaces these democratizing ideals with the imperative of leaving Tocqueville's thinking open to other serious "students of texts" to interpret.

\section{Conclusion}

In the mid-twentieth century, sociology defined itself through a retrospective operation: the creation of a canon not unlike literary and other scholarly canons. For a while, the sociological canon functioned as a metonym for the whole of sociology or as the distillation of its essence. But soon this foundation story proved untenable. As deconstructivist and critical approaches took hold of the discipline, the very notion of canonicity came under attack. In the so-called "canon wars" of the 1980s, the 
centripetal "hypercanonicity" of the 1960s came under fire and in its place, critics suggested, sociologists should open up analysis to the whole of sociology, with widely conceived temporal and spatial boundaries (Pollock, Elman, and Chang 2015). Such pleas for a centrifugal "hyperinclusiveness" came often accompanied by criticisms of the Eurocentric character of the sociological canon (e.g. Smith 1999: 423). From this perspective, canonicity was but a cunning form of "exclusivity and universality" whose real function was to mask the "erased historicity" of Western theories (Banerjee, Nigam and Pandey 2018: 46). The canon wars of the 1980s eventually brought to an end to the brief consensus about who were the sociological classics, a consensus that never really fully included Tocqueville. Even in the 1950s and 1960s, the heyday of commentary, edition, translation and original research of Tocqueville-inspired work among sociologists, the fact is that he never made it to the inner core of the canon; at best, Tocqueville and Democracy occupied a position at the fringe of the sociological canon. The discipline's growing suspicion and discontent with canonicity, in turn, made Tocqueville all the more likely to whither from view of practitioners.

This article explores the problematic of canonicity to suggest that the inclusion and exclusion of Democracy from social and political thought canons are best understood by reference to what we call the politics of the book. The politics of this book have been shown to involve collaboration, reflection, and contestation among groups of agents regarding its common meaning. At key historical junctures, these agents have intervened in the text and its material form, often with the intent of turning it into an icon, albeit with variable results.

Among political scientists, Democracy was first decanonized partly as a result of the conservative editions of the turn-of-the-twentieth-century, whose paratexts 
contributed to prevent the text from remaining an icon. Postwar conservative abridgements, by contrast, attempted to canonize it but failed, partly due to an oldfashioned version of the text as well as a crudely truncated material form. The wave of new translations of the early 2000s builds upon the momentum of the celebrations of Democracy's sesquicentennial and finally succeeds in turning the text-artifact into an icon. Largely the work of historians and political philosophers, these new editions of Democracy unmistakably frame the work as a classic in political philosophy. In the case of the controversial Mansfield-Winthrop translation, Democracy is even positioned as an icon of neoconservative ideas. This variation, pace Mancini, is a strong indication that ideological factors per se are insufficient to explain the existence of "many Tocquevilles." More significant are the ideologically charged rhetorical strategies and themes that have animated these editorial initiatives.

Among sociologists, the work has been canonized in the form of two major editorial initiatives, the Bradley and the Mayer-Lawrence editions. These editorial initiatives intervened in the text and its material form so as to make it stand for a certain way of doing political sociology. For thirty-odd years, Democracy suffered from a gradual and seemingly irreversible decanonization among sociologists.

Disciplinary developments played an important role in this, as did larger historical factors. To fully comprehend the fluctuations in the impact, reputation and scholarly standing of classical texts over time, however, one needs to consider the politics of the book. The spill over effect of the wave of new translations of the 2000s into sociology suggests that, far from irreversible, the decline in interest in the work by sociologists may be reversed as long as they are once again able to find themes and preoccupations in the text that not only resonate with but also question and expand their beliefs. That is, if sociologists are able to see in Tocqueville a representative of a 
lived tradition, whose form and content reverberate in the present.

Lived traditions are populated by classics, but not in the sense of arbitrary symbols that obtain their meanings purely from their relationships to other classics in a canon. Rather, a canon should be seen as a theoretical space of relations where positions are occupied by material signifiers alongside floating, arbitrary signifiers. As a text-artifact-metaphor, Democracy is one such material signifier. The concepts it signifies, even if not predictable, are far from arbitrary. They draw upon the properties of the signifier - the form, weight, shape, size, material, colour, and discourse of each unique copy from each edition. This means that its "death" among sociologists signalled its demise as a social object. It no longer connoted the common meaning it once had and was, for that reason, unable to help turn its readers into sociologists. Yet it also means that the recent upsurge of interest in Democracy can be but the first episode of its resurrection, especially if sociologists intent in bringing it back to life work together around its text, material form, and metaphorical standing.

This focus on the materiality of ideas is to refuse to submit to the easy choice between centripetal hypercanonicity and centrifugal hyperinclusiveness. Instead, it is a plea for clearer methodological criteria for the canonization of texts. Granted, when speaking of a "classic" authors and "classical texts" today, hardly anyone is referring simply to their "intrinsic" ability to speak meaningfully to other times and societies. Their classicality, we now know, is not built into thin air. This increased awareness has turned the study of a canon into a kind of specialized sociology. Yet to date this has also been a sociology that has overlooked "book matters", namely what can be done with and through the book form. Our pragmatic genealogy explores the materiality of theoretical agency, i.e. "the circuit of movement that a theory enacts" (Banerjee, Nigam and Pandey 2018: 47) once inscribed in a book. Such an emphasis 
in the materiality of ideas, we contend, can act as a powerful antidote against tendencies to either mythologize the past around a select few or to disregard it completely. "The master's tools will never dismantle the master's house," Audre Lord once wrote (1981: 98). Yet the master's tools are all we have if we are indeed to dismantle the master's house and build new ones. The work of theory is a work of illumination through the creation of new ways of seeing the world. The key is not to let ourselves ever fall in the error of believing that our particular way of seeing, however abstract and systematic it may be, is the only correct one. There is much to be learned from our contemporaries and our ancestors if only we are able to listen. 


\section{References}

Abbott, J. 2007. "Whither Tocqueville in American Sociology?” American Sociologist 38: 60-77.

Anderson, W. 1945. "Tocqueville, Alexis de. Democracy in America." The Annals of the American Academy of Political and Social Science 242: 182-183.

Aron, R. 1968-69. Main Currents of Sociological Thought. New York: Basic Books.

Ashley, D. and Orenstein, D.M. 2005. Sociological Theory, 6th edn. Boston: Pearson Books.

Bain, R. 1962. “The Most Important Sociologists?” American Sociological Review 27: 746-748.

Baltzell, E.D. 1962. American Business Aristocracy. New York: Collier Books.

Babchuk, N. and B. Keith 1995. "Introducing the Discipline.” Teaching Sociology 23: $215-225$.

Banerjee, P., A. Nigam and R. Pandey. 2018. "Thinking across Traditions. The Work of Theory" Economic \& Political Weekly 51: 42-50.

Baudrillard, J. 1981. For a Critique of the Political Economy of the Sign. St. Louis: Telos Press.

Bellah, R. et al. 1985. Habits of the Heart. Berkeley: University of California Press.

Bendix, R. 1964. Nation-Building and Citizenship. Berkeley: University of California Press.

Binkley, W.E. 1945. "Review: America through French Eyes.” The Scientific Monthly 61: 494-495.

Boudon, R. 2006. Tocqueville for Today. Oxford: The Bardwell Press.

Burawoy, M. 2005. "The Return of the Repressed.” Annals AAPSS 600: 68-85.

Ceaser, J. 1997. Reconstructing America. New Haven: Yale University Press. 
Colwell, J.L. 1967. “"The Calamities Which They Apprehend'.” Western Humanities Review 21: 93-100.

Connell, R.W. 1997. "Why is Classical Theory Classical?”, American Journal of Sociology 102: 1511-1557.

Commager, H.S. 1950. The American Mind. New Haven: Yale University Press.

Condren, C. 1985. The Status and Appraisal of Classic Texts. Princeton: Princeton University Press.

Cook, T.I. 1945. “Democracy in America. By Alexis de Tocqueville.” The American Historical Review 51: 131-133.

Crain, C. 2001. “Tocqueville for the neocons?” The New York Times Book Review.

Derrida, J. 1976. On Grammatology. Baltimore: Johns Hopkins University Press.

Drescher, S. 1964. “Tocqueville’s Two Démocraties.” Journal of the History of Ideas 25: 201-216.

Drescher, S. 1968a. “Tocqueville and Beaumont.” Pp. 201-217 in Tocqueville and Beaumont on Social Reform. New York: Harper \& Row.

Drescher, S. 1968b. Dilemmas of Democracy. Pittsburgh: University of Pittsburgh Press.

Elster, J. 2009. Alexis de Tocqueville. Cambridge: Cambridge University Press.

Escarpit, R. 1966. The Book Revolution. New York: Unesco Publications.

Frank, J. 1945. "Review of Democracy in America, Phillips Bradley.” Federal Bar Journal: 455-466.

Gennette, G. 1997. Paratexts. Cambridge: Cambridge University Press.

Goodwin, G.A. and Scimecca, J.A. 2005. Classical Sociological Theory. Belmont: Thomson.

Greene, L. 1945. "Review: Tocqueville on Democracy." The American Journal of 
Economics and Sociology 4: 556-558.

Guillory, J. 1994. Cultural Capital: The Problem of Literary Canon Formation. Chicago: University of Chicago Press.

Hamilton, R.F. 2003. “American Sociology Rewrites Its History.” Sociological Theory 21: 281-297.

Herrick, R.L. 1980. "Nineteen Pictures of a Discipline.” Contemporary Sociology 9: 617-621.

Kammen, M. 1998. Alexis de Tocqueville and Democracy in America. Washington, DC: Library of Congress.

Kasinitz, P. 2006. “Missing Tocqueville?” Sociological Forum 21: 693-694.

Kiniery, P. 1945. "Democracy in America." The Catholic Historical Review 31: 345347.

Kirk, R. 1953. The Conservative Mind. Chicago: Henry Regnery Company.

Laski, H.J. 1945. "Foreword”, Democracy in America (pp. i-iii). New York: Knopf.

Lawler, P. A. 1993. The Restless Mind. Lanham: Rowman \& Littlefield.

Lemert, C. 2013. Social Theory. Boulder: Westview Press.

Lipset, S.M., Trow, M. and Coleman, J. 1956. Union Democracy. New York: Anchor Books.

Livingstone, D. 2005. "Science, Text, and Space.” Transactions of the Institute of British Geographers 30: 391-401.

Lorde, A. 1981. “The Master's Tools will Never Dismantle the Master's House”. In Moraga, C. and G. Anzaldua (eds.), This Bridge Called My Back, Kitchen Table Women of Color Press, New York: 98-101.

Maccionis, J.J. 2014. Sociology. New Jersey: Pearson. Originally published in 1987. Mancini, M. 2006. Alexis de Tocqueville and American Intellectuals. Lanham: 
Rowman and Littlefield.

Mancini, M. 2008. “Too Many Tocquevilles.” Journal of the History of Ideas 69: 245-268.

Mancini, M. 2011. "From Oblivion to Apotheosis.” Journal of American Studies 45: 21-37.

Mansfield, H.C. 1995. "Self-Interest Rightly Understood.” Political Theory 23: 48-66.

Mayer, J.P. 1959a. “Tocqueville Today.” Revue Internationale de Philosophie 13: 313-319.

Mayer, J.P. 1959b. “Alexis de Tocqueville.” Revue Internationale de Philosophie 13: $350-353$.

Margree, V. and G. Bhambra 2011. "Tocqueville, Beaumont and the Silences in Histories of the United States.” Journal of Historical Sociology 24: 116-131.

Marshall, L. and S. Drescher 1968. “American Historians and Tocqueville's Democracy." The Journal of American History 55: 512-532.

Martindale, D. 1960. The Nature and Types of Sociological Theory. Boston: Houghton Mifflin.

Masugi, K. (ed.) 1991. Interpreting Tocqueville's Democracy in America. Savage, MD: Rowman and Littlefield.

McCleery, A. 2002. "The return of the publisher to book history." Book History 5: 161-185.

McKenzie, D.F. 1999. Bibliography and the Sociology of Texts. Cambridge: Cambridge University Press.

Mead, G.H. 2002. The Philosophy of the Present. Amherst: Prometheus Books.

Mead, G.H. 2011. G.H. Mead. A Reader. Abingdon: Routledge.

Meyers, M. 1957. The Jacksonian Persuasion. Stanford: Stanford University Press. 
Mumford, L. 1944. The Condition of Man. New York: Harcourt, Brace and Company.

Nisbet, R. 1976-77. “Many Tocquevilles.” The American Scholar 46: 59-75.

Nisbet, R. 1966. The Sociological Tradition. New York: Basic Books.

Olson, C. 2010. "The Sacred Book." Pp. 11-23 in The Oxford Companion to the Book, vol. 1. Oxford: Oxford University Press.

Oromaner, M.J. 1968. “The Most Cited Sociologists.” The American Sociologist 3: 124-126.

Parsons, T., E. Shils, K. Naegele, J. Pitts (eds.) 1961. Theories of Society. New York: Free Press.

Peirce, C.S. 1955. The Philosophical Writings of Peirce. New York: Dover.

Perrucci, R. 1980. "Sociology and the Introductory Textbook." The American Sociologist 15: 39-49.

Pierson, G. W. 1938. Tocqueville and Beaumont in America. Oxford: Oxford University Press.

Pollock, S., B. A. Elman, and K. Chang. 2015. World Philology. Cambridge, MA: Harvard University Press.

Putnam, R. D. 1993. Making Democracy Work. Princeton: Princeton University Press.

Resh, R.W. 1963. “Alexis De Tocqueville and the Negro.” The Journal of Negro History 48: 251-259.

Runciman, D. 2018. The End of Democracy. New York: Basic Books.

Rupke, N. 1999. “A Geography of Enlightenment.” Pp. 319-339 in Geography and Enlightenment. Chicago: University of Chicago Press.

Salomon, A. 1935. “Tocqueville, Moralist and Sociologist.” Social Research 2: 405427.

Salomon, A. 1959. “Tocqueville, 1959.” Social Research 36: 449-470. 
Saussure, F. de. 1983. Course in General Linguistics. London: Duckworth.

Schleifer, J.T. 1980. The Making of Tocqueville's Democracy in America. Chapel Hill: University of North Carolina Press.

Scott, J. 1990. A Matter of Record. Cambridge: Polity Press.

Secord, J. 2001. Victorian Sensation. Chicago: University of Chicago Press.

Seidman, S. 2012. Contested Knowledge. London: Wiley-Blackwell.

Silva, F.C., M.B. Vieira. 2019. The Politics of the Book. University Park, PA: Penn State University Press.

Sydnor, C.S. 1945. "Democracy in America.” Political Science Quarterly 60: 457459.

Smith, L.T. 1999. Decolonizing Methodologies. London: Zed Books.

Swedberg, R. 2009. Tocqueville's Political Economy. Princeton: Princeton University Press.

Torpey, J. 2006. “Alexis de Tocqueville.” Sociological Forum 21: 695-707.

Turner, J. 1998 The Structure of Sociological Theory, $6^{\text {th }}$ edn. Belmont: Wadsworth.

Welch, C. 2001. De Tocqueville. Oxford: Oxford University Press.

Winthrop, D. 1986. “Tocqueville's American Women and 'The True Conception of Democratic Progress." Political Theory 14: 239-61.

Wright, B.F. 1946. "Of Democracy in America." The American Political Science Review 40: 52-61.

\section{Endnotes}

\footnotetext{
${ }^{1}$ Until the eve of World War I, Democracy was published in the United States in 46 different printings,
} 
including many abridgements adapted for the use of schools and district libraries; see Bradley 1945: xxii.

${ }^{2}$ Letter from Salomon to Knopf, 26 March 1945. Alfred A. Knopf Archive (herewith KA).

${ }^{3}$ The Knopf Archive, which includes the materials pertaining to this edition of Democracy is held at the Harry Ransom Center, University of Texas at Austin.

${ }^{4}$ Letter to Knopf, January 24, 1946. KA.

${ }^{5}$ Letter from Knopf to Bradley, January 16 1951. KA.

${ }^{6}$ The Commager edition appeared in the United States in 1947. Relevant materials are in the Oxford University Press Archive (OUP Archive) in Oxford.

${ }^{7}$ Letter to Hatcher, New York branch of OUP, 7 September 1944. OUP Archive.

${ }^{8}$ 20,829 balance at 1 April 1960. OUP Archive.

${ }^{9}$ Letter to OUP, New York of 21 February, 1961.

${ }^{10}$ Harper \& Row's records (herewith HR), which include materials pertaining to this edition of Democracy in America, are held at the Rare Book and Manuscript Library, Columbia University.

${ }^{11}$ In order to ensure comparability with previous studies, we have analysed ten textbooks from each of the following four periods: 1958-1962; 1963-1967; 1968-1972; 1973-1977 (Bain 1962; Oromaner 1968; Perrucci 1980); and nineteen from the 1978-1980 period (Herrick 1980). The complete list of textbooks is available in Perrucci (1980: 41) and Herrick (1980: 625-6).

${ }^{12}$ Babchuk and Keith (1995) focus on the four of the "most widely adopted comprehensive introductory sociology textbooks" (1995: 216) for analysis. Using this criterion to analyse the 19801997 period, we find Tocqueville's Democracy being cited at least twice in Persell (1990) and in Hess et al. (1991), even though in this case one of these references is actually about Harriet Martineau's Society in America, not Democracy in America. In short, in only one of the four most widely adopted sociology textbooks in the 1980s and 1990s do we find the slightest of references being made to Democracy. Moving on to the 1990s and 2000s, Hamilton reaches a similar conclusion. He shows that in 17 textbooks published between 1997 and 2000, Tocqueville is mentioned in only seven (Hamilton 2003: 292). Finally, regarding the $2000-2015$ period, our analysis shows that Tocqueville's presence is residual at best. Maccionis' Sociology (2014), the most influential textbook in America today, does not list Democracy in its references, and virtually all eight mentions of Tocqueville in the text (or in the notes) are superficial. A similar pattern emerges in other textbooks. Henslin (1999: 177) makes one 
reference to Tocqueville (on voluntary associations), while Schaefer (2001) and Kendall (2011) make no reference to Tocqueville. Textbooks of sociological theory offer a similar picture. Turner (1998), Ashley and Orenstein (2005), Goodwin and Scimecca (2005), Edles and Applerouth (2005) make no reference to Tocqueville.

${ }^{13}$ Although ISA members were asked to list "five books published in the twentieth century which were most influential in their work as sociologists," several books published in the $19^{\text {th }}$ century were listed (e.g. Marx’s 1867 Capital). Democracy in America was not one of them. See: http://www.isasociology.org/en/about-isa/history-of-isa/books-of-the-xx-century/ranking-order/ 